\title{
ФОРМУВАННЯ ПРАКТИЧНИХ НАВИЧОК ВИКОРИСТАННЯ ПРЯНО-АРОМАТИЧНИХ РОСЛИН В КУРСІ «ФІТОЛОГІЯ» ДЛЯ СТУДЕНТІВ СПЕЦІАЛЬНОСТІ «ЗДОРОВЯ ЛЮДИНИ»
}

\author{
Мегалінська Г. П., дочент \\ Страшко С. В., проф. \\ Сікура А. Й., проф. \\ Білик Ж. І., к. б. н. \\ Україна, Київ, Кафедра медико-біологічних та валеологічних основ охорони життя $і$ здоров'я \\ Національний педагогічний університет імені М.П. Драгоманова
}

DOI: https://doi.org/ 10.31435/rsglobal_ws/31102018/6181

\section{ARTICLE INFO}

Received: 08 August 2018

Accepted: 14 October 2018

Published: 31 October 2018

\section{KEYWORDS}

Spice-aromatic plants, antibacterial activity, biological experiment.

\begin{abstract}
The results of the study of determination of the ways of formation in the course "Phytology" of future teachers of the basis of health of practical skills of using spice-aromatic plants are presented. The work is devoted to the study of the pedagogical efficiency of using the disco diffusion method for studying the antibacterial activity of spicy aromatic plants. It is shown that the level of assimilation of knowledge increases by $9 \%$.
\end{abstract}

Citation: Мегалінська Г. П., Страшко С. В., Сікура А. Й., Білик Ж. І. (2018) Formuvannia Praktychnykh Navychok Vykorystannia Priano-Aromatychnykh Roslyn v Kursi «Fitolohiia» Dlia Studentiv Spetsialnosti «Zdorovia Liudyny». World Science. 10(38), Vol.2. doi: 10.31435/rsglobal_ws/31102018/6181

Copyright: (C) 2018 Мегалінська Г. П., Страшко С. В., Сікура А. Й., Білик Ж. І. This is an openaccess article distributed under the terms of the Creative Commons Attribution License (CC BY). The use, distribution or reproduction in other forums is permitted, provided the original author(s) or licensor are credited and that the original publication in this journal is cited, in accordance with accepted academic practice. No use, distribution or reproduction is permitted which does not comply with these terms.

Вступ. Через стрімку зміну умов життя сучасної людини, погіршення екологічної ситуації, падіння рівня здоров'я населення, в тому числі дітей та підлітків, обгрунтовано висуваються вимоги до професійних педагогів 3 основ здоров’я, які навчатимуть учнів правилам і засобам зміцнення та збереження здоров'я. Серед загального обсягу знань, якими мають оволодіти студенти, треба наголосити на знаннях 3 курсу «Фітологія», які стосуються не тільки питань використання харчових рослин і небезпеки отруйних рослин, а й питань фітотерапії. В розробленій нами програмі спецкурсу «Фітологія» $є$ тема «Пряно-ароматичні рослини». Оволодіння знаннями в обсягах цієї дисципліни підкреслює необхідність підвищення зв’язку теорії з практикою. Знання основних біологічних особливостей лікарських, їстівних та отруйних рослин, їх біохімічних характеристик, уміння використовувати ці рослини у практичній діяльності - це підгрунтя, на якому базується успішна майбутня професійна діяльність вчителя предмету «Основи здоров’я» [3].

Необхідно зазначити, що за даними ВО3, широке використання синтетичних (отриманих шляхом хімічного синтезу) засобів у якості харчових добавок до продуктів харчування, ліків, парфумерії, косметики, засобів гігієни призвело до алергізації майже п'ятої частини населення [1]. В усьому світі спостерігається стійка тенденція зростання зацікавленості у використанні як культивованих, так і дикоростучих лікарських і пряно-ароматичних рослин. Це пов'язано з їх здатністю синтезувати й акумулювати сотні, а іноді й тисячі біологічноактивних речовин (БАР). 
Знання класифікації пряно-ароматичних рослин, їх біохімічного складу та шляхів застосування $\epsilon$ важливим аспектом підготовки вчителів «Основ здоров’я» та організаторів валеологічної служби.

Аналіз останніх досліджень і публікацій. Як відмічається у численних літературних джерелах, протягом багатьох тисячоліть рослини природної флори вірно служать людині у багатьох сферах життя $[1,6,12]$. Наприклад, пряно-ароматичні рослини не лише покращують нам їжу, але й посідають гідне місце в арсеналі лікувальних засобів. Проте, аби правильно, влучно та 3 користю використовувати ці рослини, треба добре знатися на їх особливостях $\mathrm{i}$ властивостях. Тим більше, що вся історія українського етносу підтверджує широке використання лікарських і пряно-ароматичних рослин у повсякденному житті та з лікувальною і профілактичною метою [2].

Використання пряно-ароматичних рослин разом 3 їжею регулює фізіологічний та психологічний стан організму людини, сприяє найбільш повноцінному засвоєнню їжі, стимулює очисні, метаболічні та захисні функції нашого організму. Крім того, деякі пряноароматичні рослини володіють здатністю пригнічувати розвиток бактерій гниття, чим сприяють тривалішому зберіганню іжі $[3,10]$. Переважна більшість пряно-ароматичних рослин здатна активізувати виведення шлаків 3 організму, а також відігравати роль каталізаторів у низці ферментативних процесів. Саме тому більшість відомих пряно-ароматичних рослин у наш час, а тим більше у минулому використовувались медиками в якості лікарських засобів [2]. Проте, у літературних джерелах практично відсутня інформація щодо педагогічних засобів формування практичних навичок роботи конкретно з пряно-ароматичними рослинами, проведення 3 ними наукових експериментів майбутніми педагогами.

Мета, завдання наукової праці. Мета статті полягає у визначенні педагогічних умов формування в курсі «Фітології» у майбутніх учителів основ здоров’я практичних навичок використання пряно-ароматичних рослин.

Завдання: 1) провести аналіз науково-педагогічної, методичної та ботанічної літератури 3 означеного питання; 2) конкретизувати видовий склад групи пряно-ароматичних рослин, які можна використовувати на лабораторних заняттях, з'ясувати їх хімічний склад і властивості; 3 ) визначити педагогічні умови формування практичних навичок дослідницької діяльності 3 живим рослинним матеріалом.

Методи дослідження: аналіз і узагальнення літературних і отриманих емпіричних даних, методи анкетування, бесіди, лабораторних досліджень, порівняння, узагальнення, статистичного аналізу.

Виклад основного матеріалу. Формування практичних навичок відбувається безпосередньо у процесі навчання. За визначенням В.О. Артемова, навичка характеризується як автоматизоване вміння, яке стало в результаті численних і цілеспрямованих повторень найбільш економним і вільним способом виконання даної дії. Зрозуміло, що навичка визначається вмінням. Відтак, база вміння - знання $[2,3]$.

Ознайомити студентів - майбутніх вчителів основ здоров'я 3 групами отруйних, харчових і лікарських рослин покликана дисципліна «Фітологія», що викладається в межах освітньо-професійної програми підготовки бакалаврів за напрямом «Здоров’я людини» i забезпечує зміст одного зі спецкурсів. Програмою передбачений наступний розподіл годин: 10 год. лекцій, 14 год. лабораторних занять, 4 год. індивідуальної роботи та 26 год. самостійної роботи студентів. Видом контролю навчальних досягнень виступає залік. В процесі вивчення фітології студенти повинні оволодіти знаннями про будову і властивості рослин на всіх рівнях їх організації, що $\epsilon$ необхідним у професійній діяльності учителя основ здоров'я. Теоретичний матеріал включає відомості про еколого-біологічні особливості рослин, специфіку їх поширення, анатомічну та морфологічну будову, видовий склад лікарських i пряноароматичних рослин усіх систематичних груп, вміст біологічно-активних речовин та можливості їх використання.

Пряно-ароматичні рослини містять унікальні антиоксиданти, ефірні олії, вітаміни, володіють здатністю пригнічувати ріст і розвиток бактерій, в тому числі патогенних, що дозволяє цим рослинам впливати як на фізичне, так і на психологічне здоров'я людини. За даними [5] вживання пряноароматичних рослин підвищує адаптаційні властивості людини до екстремальних умов.

Проте аби кваліфіковано та 3 користю застосовувати пряно-ароматичні рослини, необхідно добре знатися на їх особливостях і властивостях. Набуття таких знань майбутніми вчителями основ здоров'я забезпечує зміст дисципліни «Фітологія», яка є складовою переліку дисциплін професійної та практичної підготовки бакалаврів за напрямом «здоров'я людини». 
Навчання починається з ознайомлення студентів із біологічними особливостями певних рослинних об'єктів, уточнення їх систематичного положення, з'ясування особливостей їх біохімічного складу. Студенти навчаються правильно збирати рослини, висушувати їх, складати та оформлювати гербарій, опановують методики лабораторного виділення біологічно активних речовин, що містяться в тих чи інших органах рослин, а також приготування екстрактів (настоянок) з висушеної сировини.

Для формування практичних навичок нами використовувалося два методичних прийоми, - лекція на тему «Значення пряно-ароматичних рослин для здоров’я людини» та лабораторна робота «Вивчення антибактеріальних властивостей пряно-ароматичних рослин». Лабораторний метод - це самостійне проведення студентами експериментів, дослідів 3 використанням устаткування, інструментарію, тобто, 3 використанням спеціального обладнання. Лабораторний метод забезпечує не лише набуття студентами знань, а й підтримує інтерес до навчання, спонукає до подальших досліджень, сприяє формуванню практичних умінь і навичок. Такі практичні роботи виконують функції поглиблення знань, закріплення умінь, контролю і корекції, стимулюють пізнавальну діяльність, підвищують мотивацію, сприяють розвитку самостійності та творчої активності студентів [4].

Всі пряно-ароматичні рослини володіють антибактеріальною активністю, тому важливо було розробити методику лабораторної роботи по визначенню антибактеріальної активності пряно-ароматичних рослин по відношенню до різних умовно-патогенних бактерій. Студенти спеціальності «Здоров'я людини» вивчали дисципліну «Мікробіологія, вірусологія, імунологія» на III-му курсі, - тому з мікробіологічними методиками ознайомлені.

Для проведення лабораторної роботи потрібно наступне обладнання: чашки Петрі, стерильні шприци, середовище МПА, стерильні диски, чисті культури досліджуваних санітарно-показових бактерій. Водні витяжки різних видів пряно-ароматичних рослин у кількості не менше 5 г.

Навчальна діяльність спрямована на озброєння студентів знаннями, уміннями та навичками. Але крім цього А.Н. Лук виділяє необхідність інтеграції в навчальний процес творчих ситуацій. Творчі ситуації стимулюють пошукову діяльність студентів, розвивають їх творчі здібності, що сприяє розвитку креативних рис особистості. Тому при розробці методики проведення лабораторної роботи «Антибактеріальна активність пряно-ароматичних рослин» ми використали творчу ситуацію, - яка з пряно-ароматичних рослин потрібна для оздоровлення людини при різних типах патологічних станів.

Враховуючи сучасний стан наукової літератури $[5,6,7,10,11,12]$ нами було обрано наступні об'єкти дослідження для лабораторної роботи, - перець чорний, куркума, імбир, петрушка та лепеха (аїр болотний).

Для вивчення антибактеріальної активності застосовувався метод паперових дисків.

Суть методу полягає в тому, що диски фільтрувального паперу просочують розчином, який вивчається, і кладуть на поверхню агаризованого середовища, останнє засіяне тест культурою [7]. Цей метод широко застосовується у медицині при підборі антибактеріальних препаратів у лікарській практиці.

Результати лабораторного досліду студенти заносять у таблицю 1.

Таблиця 1. Антибактеріальна та фунгіцидна активність екстрактів деяких пряно-ароматичних рослин

\begin{tabular}{|c|c|c|c|c|c|}
\hline \multirow{2}{*}{$\begin{array}{c}\text { мест- } \\
\text { мікроорганізми }\end{array}$} & \multicolumn{5}{|c|}{ Зона лізісу / мм } \\
\cline { 2 - 6 } & $\begin{array}{c}\text { перець } \\
\text { чорний }\end{array}$ & куркума & імбир & петрушка & $\begin{array}{c}\text { аїр } \\
\text { болотяний }\end{array}$ \\
\hline $\begin{array}{c}\text { кишкова } \\
\text { паличка }\end{array}$ & 0 & 0 & 0 & 8 & 0 \\
\hline $\begin{array}{c}\text { золотистий } \\
\text { стафілококк }\end{array}$ & 8 & 9 & 0 & 9 & 8 \\
\hline чудова паличка & 9 & 11 & 9 & - & 8 \\
\hline сінна паличка & 0 & 20 & 0 & 0 & 11 \\
\hline кандіда біла & 20 & 14 & 0 & 12 & 12 \\
\hline $\begin{array}{c}\text { синьогнійна } \\
\text { паличка }\end{array}$ & 7 & 16 & 11 & 7 & 9 \\
\hline сарцина жовта & 8 & 10 & 10 & 12 & 9 \\
\hline
\end{tabular}


Зона гальмування, діаметр якої представлено у таблиці, - це зона, де відбувається лізіс бактеріальних клітин, iї розміри пропорційні антибактеріальній активності субстрату [11].

3 емпіричних даних зрозуміло, що найбільш активно пригнічує ріст гриба кандіди білої витяжка 3 насіння перцю чорного. Перець чорний також активно пригнічує розвиток чудової палички, синьогнійної палички, сарцини жовтої і стафілококка золотистого, не впливаючи при цьому на кишкову паличку, яка завжди присутня у кишковому тракті людини і $є$ його необхідним компонентом. Витяжка із кореневища імбиру виявила антибактеріальну активність по відношенню до бактерій гниття - чудової палички, синьогнійної палички, сарцини жовтої. Імбир не впливає на кандіду білу, кишкову паличку, сінну паличку і золотистий стафілококк, що свідчить про слабкий ендоекологічний вплив цієї рослини в мікроценозах. Екстракт куркуми виявив сильний антибактеріальний ефект по відношенню до сінної палички, дещо менший проти синьогнійної палички і кандиди білої, майже не виявив антибактеріальних властивостей по відношенню до сарцини жовтої і стафілококка золотистого, відсутнє пригнічення кишкової палички. Екстракт, виділений із аїру болотяного, проявляє середню антибактеріальну активність відносно кандиди білої, синьогнійної палички, сарцини жовтої, золотистого стафілококку та чудової палички. Петрушка виявила значний антибактеріальний ефект відносно кандіди білої та сарцини жовтої та менший відносно золотистого стафілокока та кишкової палички.

Отримані дані дозволили студентам дійти висновків про те, що чорний перець найбільш корисний для ендоекології людського і рослинного організмів. Ця рослина згубно впливає на хвороботворні бактерії і гриби, ніяк не впливаючи на позитивного симбіонта людського організму - кишкову паличку і стимулює розвиток симбіонта рослинного організму - сінну паличку. Водна і лектинова витяжка із кореневища імбиру має слабку антибактеріальну активність відносно бактерій гниття, не впливаючи на симбіонтів людського організму. Тобто, ефект цієї рослини можна розглядати насамперед як екзоекологічний.

В педагогічному експерименті брали участь 2 групи студентів по 50 осіб в кожній. В одній групі заняття проводили лекційним методом, а в іншій проводилася лабораторна робота 3 елементами біологічного експерименту. До проведення експерименту рівень знань студентів обох груп оцінювався в констатувальному експерименті методом анкетування. Після формувального експерименту також оцінювався рівень знань студентів. Анкета складалася з 10 питань у вигляді тестів закритого типу з однією правильною відповіддю.

Для оцінювання навчальних досягнень студентів було прийнято наступну шкалу. Одна правильна повна відповідь на запитання анкети оцінювалась в один бал, неправильна або частково - 0 балів. Сумарний максимальний бал для одного студенту дорівнював - 10 (Таблиця 2).

Таблиця 2. Шкала діагностики рівня навчальних досягнень студентів

\begin{tabular}{|c|c|l|}
\hline $\begin{array}{c}\text { Рівень } \\
\text { навчальних } \\
\text { досягнень }\end{array}$ & $\begin{array}{c}\text { Кількість } \\
\text { балів }\end{array}$ & \multicolumn{1}{|c|}{ Рівень валеологічної підготовки } \\
\hline Низький & $1-3$ & $\begin{array}{l}\text { Низький рівень валеологічної підготовки - це діяльність не } \\
\text { спрямована на вирішення валеологічних завдань. } \\
\text { Ставлення до валеологічних знань байдуже, система знань i } \\
\text { готовність їх використовувати відсутні }\end{array}$ \\
\hline Середній & $4-7$ & $\begin{array}{l}\text { Середній рівень відрізняться проявом тенденцій до } \\
\text { стійкого ціннісного ставлення стосовно валеологічних } \\
\text { питань. Властиві більш висока оцінка значення } \\
\text { валеологічних знань і тенденція до ї поглиблення. }\end{array}$ \\
\hline Високий & $8-10$ & $\begin{array}{l}\text { Високий рівень відрізняється високим рівнем } \\
\text { валеологічним знань, іх тенденцією до оновлення і } \\
\text { поглиблення, наявністю стійких валеологічних цінностей. В } \\
\text { діяльності важливе місце займають такі форми творчої } \\
\text { активності, що забезпечують продуктивне вирішення } \\
\text { валеологічних завдань. }\end{array}$ \\
\hline
\end{tabular}

Як свідчить аналіз констатувального експерименту високий рівень навчальних досягнень мали лише 4\% респондентів, і тільки 40,2 відсотки мали середній рівень. 
Таблиця 3. Критеріальна оцінка засвоєння студентами теми «Пряно-ароматичні рослини» за допомогою лабораторного методу з використанням біологічного експерименту та лекційного методу навчання

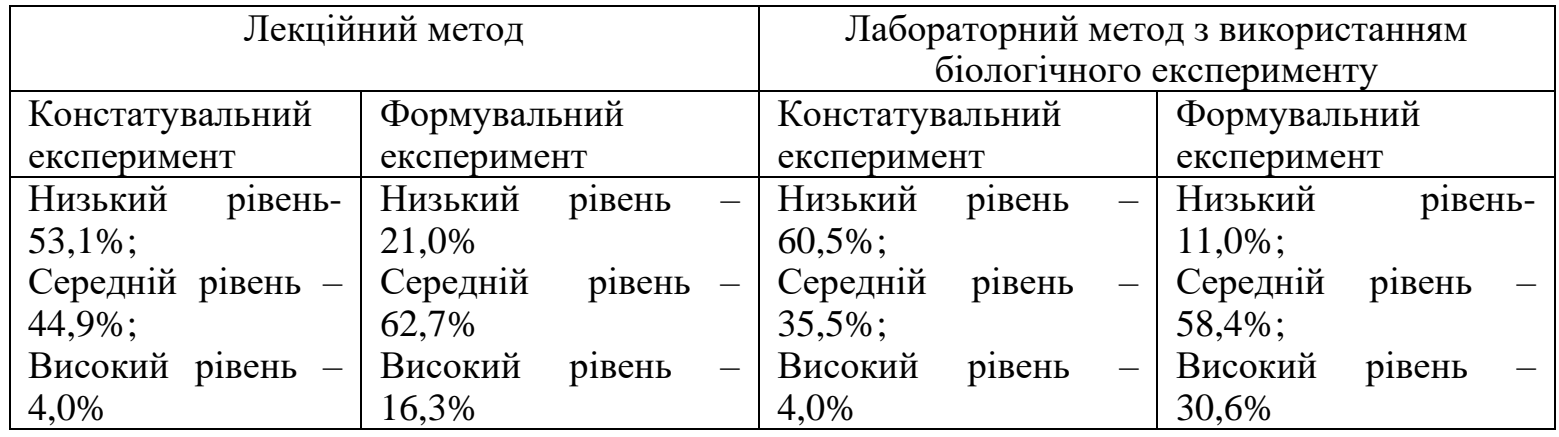

Відповідно до результатів дослідження застосування лекційного метода зумовлює зменшення кількості студентів з низьким рівнем знань приблизно на $32 \%$, збільшення кількості студентів 3 високим рівнем знань на $12 \%$, при цьому кількість студентів з середнім рівнем знань збільшується на $17,8 \%$. Застосування лабораторного метода 3 використанням біологічного експерименту значно збільшує кількість студентів 3 високим рівнем знань відповідно на 26\%, кількість студентів з низьким рівнем знань зменшується на $49 \%$.

Для математичної обробки отриманих даних застосовувався коефіцієнт засвоєння знань $\mathrm{k}^{-}$за методом О.О. Ківерляга [13]:

$$
\bar{k}=\frac{\sum I_{a}^{\prime}}{N \cdot I_{a}} \cdot 100 \%
$$

де $I_{a}$ - загальна кількість елементів знань, що підлягає перевірці;

$\sum I_{a}^{\prime}$ - сума засвоєних елементів знань студентів обраної групи;

$I_{a}^{\prime}$-кількість засвоєних елементів знань;

$N$ - загальна кількість студентів обраної групи. Результати дослідження подано таблиці 4.

Таблиця 4. Рівень засвоєння знань студентами, обчислено методом О. О. Ківерляга

\begin{tabular}{|c|c|c|c|}
\hline \multicolumn{2}{|c|}{ Лекційний метод } & \multicolumn{2}{|}{$\begin{array}{c}\text { Лабораторний метод з використанням } \\
\text { біологічного експерименту }\end{array}$} \\
\hline $\begin{array}{c}\text { Констатувальний } \\
\text { експеримент }\end{array}$ & $\begin{array}{c}\text { Формувальний } \\
\text { експеримент }\end{array}$ & $\begin{array}{c}\text { Констатувальний } \\
\text { експеримент }\end{array}$ & $\begin{array}{c}\text { Формувальний } \\
\text { експеримент }\end{array}$ \\
\hline $11 \%$ & $15 \%$ & $9 \%$ & $18 \%$ \\
\hline
\end{tabular}

Як свідчать результати статистичної обробки даних педагогічного експерименту за методом О. О. Ківерляга розроблений нами лабораторний метод з використанням біологічного експерименту підвищує рівень знань на $9 \%$.

Висновки. Проведене дослідження дозволило дійти висновків про те, що формування у студентів практичних навичок роботи з рослинними об'єктами з групи пряно-ароматичних рослин забезпечується за дотримання таких педагогічних умов: 1) використання навчально-методичних матеріалів і підходів для оволодіння студентами теоретичними знаннями з дисципліни «Фітологія»; 2) опанування комплексом методик лабораторного виділення біологічно-активних речовин; 3) забезпечення необхідного лабораторного устаткування; 4) розвитку та підтримання інтересу до навчання, стимулювання пізнавальної діяльності та мотивації.

У перспективі для підвищення ефективності професійної підготовки майбутніх учителів основ здоров'я слід вирішити питання розширення переліку живих об'єктів, особливості яких можуть досліджуватись у лабораторних умовах на навчальних заняттях. 


\section{ЛІТЕРАТУРА}

1. Мегалінська Г. П., Костирко О. О. Фітогемаглютиніни та їх вплив на здоров'я людини / Г. П. Мегалінська, О. О. Костирко // Фізіологія людини і тварин.- 2011.- С. 132-138.

2. Мегалінська Г. П., Морозюк С. С., Афанасьєва І. Ф. Вивчення цитостатичної активності деяких рослин-радіопротекторів: Збірник // Сучасний стан та перспективи розвитку природничогеографічних наук і освіти.- К.: НПУ,1999.- С. 38-40.

3. Сікура А. О. Методи підвищення пізнавальної активності студентів при вивченні мікробіології [Текст] / А. О. Сікура // Молодий вчений; № 12 (27), Частина 4.- 2015.

4. Сікура А. О. Навчання і розвиток пізнавальних здібностей студентів при проведенні спостережень у предметних дослідженнях // Матеріали X Міжнародної науково-практичної конференції „Вища освіта України у контексті інтеграції до європейського освітнього простору” 19-21 листопада 2015 року, м. Київ; Том V (65) «Психологічні, педагогічні та організаційні умови запровадження європейських стандартів вищої освіти.- С. 446-453.

5. Х Хасин К. М., Мидлер А. П. Пряности. Лечебные и кулинарные свойства. - Издательство «Общество САТТВА» Санкт-Петербург, 2001 - 173с.

6. Alavijeh P. K. A study of antimicrobial activity of few medicinal herbs / Parastoo Karimi Alavijeh, Parisa Karimi Alavijeh and Devindra Sharma // Asian Journal of Plant Science and Research. - 2012. - 2 (4). - P. $496-502$.

7. Antara Sen. Evaluation of antimicrobial activity of different solvent extracts of medicinal plant: Melia azedarach L. Antara Sen, Amla Batra // Int J Curr Pharm Res. - 2010. - Vol 4, Issue 2. - P. 67 - 73.

8. Antimicrobial activity of some medicinal plants against multidrug resistant skin pathogens / Maher Obeidat // Journal of Medicinal Plants Research. - 2011. - Vol. 5(16). - P. 3856 - 3860.

9. Haznedaroglu MZ, Karabay NU, Zeybek U. Antibacterial activity of Salvia tomentosa essential oil. Fitoterapia. - 2001.- Nov;72(7):829-31.

10. Hossain MM, Paul N, Sohrab MH, Rahman E, Rashid MA. Antibacterial activity of Vitex trifolia. Fitoterapia. - 2001.- Aug;72(6):695-7.

11. Study Antimicrobial Activity of Lemon (Citrus lemon L.) Peel Extract / Maruti J. Dhanavade, Chidamber B. Jalkute, Jai S. Ghosh and Kailash D. Sonawane // British Journal of Pharmacology and Toxicology. 2011. - Vol. 2(3). - P. $119-122$.

12. Sumathi P. Antimicrobial activity of some traditional medicinal plants / P. Sumathi and A. Parvathi // Journal of Medicinal Plants Research. - 2010. - Vol. 4(4). - P. 316 - 321.

13. Киверляг А.А. Методы исследования в профессиональной педагогике. - Таллин: Валгус, 1980. - 334 с. 